\title{
INDICATORS OF SUB-DAILY HYDROLOGICAL ALTERATIONS
}

\author{
Darko Barbalić, Neven Kuspilić
}

Preliminary notes

Ecological status, according to EU Water Framework Directive, is an expression of the quality of the structure and functioning of aquatic ecosystems associated with surface waters. It can be compromised by different forms of hydrological alterations. In this paper some aspects of fast and frequent fluctuations of discharge, most often caused by production of electric energy to meet peek demands or so called "hydro-peaking" has been studied. Two "hydro-peaking" indicators defined in CEN guidance standard have been evaluated for the undisturbed gauging stations in the Danube River basin in Croatia and correlated to watershed size descriptors and fitting Indicators of Hydrological Alterations. Additional third indicator based on discharge, analogous to indicator from CEN, was introduced and studied in the same way. Results have revealed that on majority of examined gauging stations values of indicators exceed boundaries for "near-natural" and "slightly modified" state. It appears that the use of analogous discharge based indicator instead of level based indicator has some advantages such as easier application and potential for more reliable regionalisation. Reliability of relationship of the third hydro-peaking indicator, based on hourly flow data, to Indicators of Hydrological Alterations, based on daily flow data, indicates the possibility of using significantly larger pool of daily data for definition of reference (undisturbed) conditions for sub-daily flow variations.

Keywords: Danube River basin; hydromorphology; hydro-peaking; Indicators of Hydrological Alterations

Indikatori unutardnevnih hidroloških promjena

Prema EU Okvirnoj direktivi o vodama, ekološki status je izraz kvalitete strukture i funkcioniranja vodnih ekosustava povezanih s površinskim vodamá.enje Ekološki status rijeka mogu ugroziti različite vrste hidroloških promjena. U ovom radu analizirani su neki aspekti brzih i čestih promjena protoka, najčešće vezanih za proizvodnju vršne energije odnosno tzv. "hydro-peaking". Dva "hydro-peaking" indikatora definirana CEN standardom su proračunata na hidrološkim stanicama koje nisu pod značajnim antropogenim utjecajima na slivu rijeke Dunav u Hrvatskoj te je provedena analiza njihove korelacije s deskriptorima veličine sliva i odgovarajućim indikatorima hidroloških promjena. Isti postupak je proveden i za treći indikator zasnovan na protoku a koji je analogan indikatoru iz CEN standarda koji se zasniva na nivou vode. Rezultati su pokazali da vrijednosti indikatora na većini analiziranih stanica premašuju granice ,približno prirodnog“ i „malo izmjenjenog“ stanja. Također čini se da korištenje indikatora zasnovanog na protoku umjesto analognog zasnovanog na nivou ima određene prednosti kao što su lakša primjena i mogućnost pouzdanije regionalizacije. Pouzdanost odnosa trećeg „hydro-peaking“ indikatora, proračunatog na osnovu satnih podataka, sa indikatorima hidroloških promjena, proračunatim na osnovu dnevnih podataka, ukazuje na mogućnost korištenja značajno većeg skupa dnevnih podataka za proračun referentnih (prirodnih) unutardnevnih hidroloških promjena.

Ključne riječi: hidromorfologija; hydro-peaking; indikatori hidroloških promjena; sliv rijeke Dunav

\section{Introduction}

Hydrological alterations, regardless of their cause, influence ecological status of rivers, preservation and protection of which is one of the priority activities of water management. Consequently, identification of importance of certain hydrological parameters for preservation of good ecological status, on one side and evaluation of their alterations on the other side adds to comprehensive and more efficient water protection.

Water framework directive (WFD, [1]), implemented in Croatian legislation, provides quite clear structure and systematic approach to water management. However in most cases, detailed application is left to member states, having in mind their natural and social circumstances.

Link between hydrological indices and biological indices by which ecological status of river is defined is not clear, although it can be stated that in most cases increase of hydrological alteration is followed by increased risk to achieve good ecological status [2]. On this foundation also WFD approach is based, by which it is required to define reference conditions, evaluate certain indicators for rivers in undisturbed pristine state, which are used for assessment of level of modification of that state. For reliable water management and application of operative activities it is clear that these indicators should be good descriptors of ecological status of rivers as well as easily applicable in operational day-to-day water management. However lack of data as well as lack of research cannot justify deterioration of good status.
Nevertheless, it is acceptable to adjust standards in sixyear planning cycles.

The oldest and traditionally the most studied element of ecological flows is "biological minimum" or "hands off flow", generally speaking the lowest discharge which has to be retained in stream to enable survival of ecosystems. However, it was realised that biological minimum is not the only requirement needed to reach good ecological status, and that ecological status is influenced by a set of other hydrological features. One of such characteristics is fast and frequent fluctuations of the flow often caused by production of electric energy to meet peek demands or so called "hydro-peaking". Such activities, apart from direct alteration of hydrologic regime, can also cause significant adverse ecological impacts, what has been subject of many studies, as well as sometimes directly endanger human lives. In Fig. 1, as example of different flow dynamics, hydrographs of two gauging stations at close sub watersheds of the Kupa River and of comparable sizes are shown. Gauging station Donje Stative at the Dobra River, is under direct influence of hydroelectric power plant Gojak while at watershed of gauging station Veljun at the Korana River, there are no significant structures which could produce such type of disturbance. It is certain that such fast flow fluctuations on the Dobra River are accompanied by substantial modifications of other hydromorphological features (surface and ground water levels, turbidity, sediment transport, bank stability etc.) and consequently leading to deterioration of ecological state. 
Indicators of hydrological alterations (IHA, [3, 4]) consist of 33 parameters which are considered to be rather good descriptors of hydrological regime characteristics which influence ecological status of rivers. Together with "Range of the Variability Approach" method, they become one of the most frequently used hydrological methods for assessment of alteration of hydrological regime which can influence ecosystems [5]. Consequently, it can be assumed that it can be one of the bases for exploration of such phenomena in the Danube River basin in Croatia. Indicators which are the most appropriate for description of alterations caused by hydro- peaking are placed in indicator subgroup 5, "Rate/Frequency of Water Condition Changes" and they are:

- $I H A_{5.1}$, "means of all positive differences between consecutive daily values"

- $I H A_{5.2}$, "means of all negative differences between consecutive daily values"

- $I H A_{5.3}$, "number of hydrological changes".

As IHA are based on analysis of daily flow data it can be expected that they are not appropriate for description of sub-daily variations of flow such as hydro-peaking.

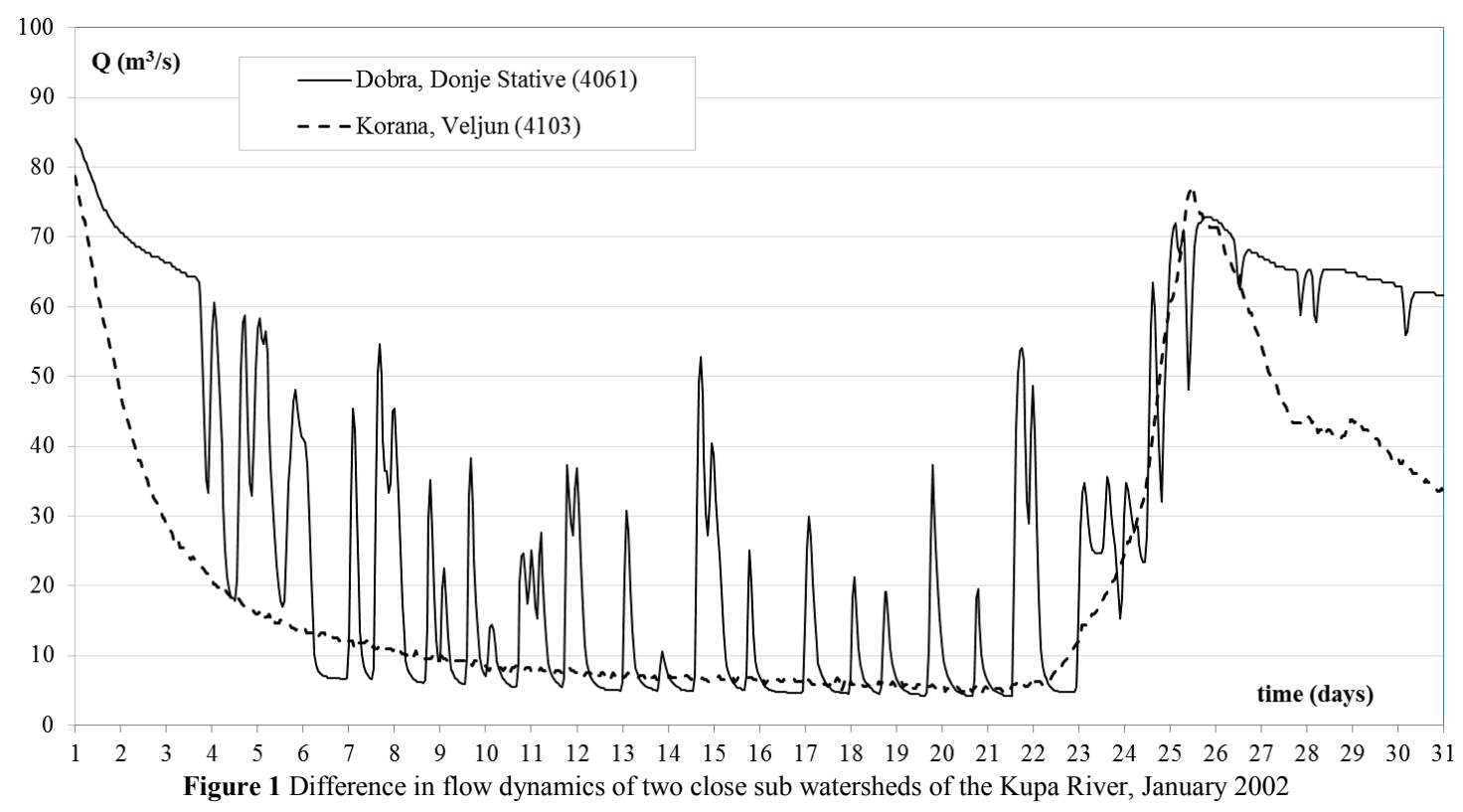

Fig. 2 depicts reducing of the sub-dailyfluctuations of flow if daily information is used. Hourly flow data is presented with corresponding daily averages of hourly flows (current practice for calculation of daily data) and simulated daily reading of the staff at 7 o'clock (as standard practice before introduction of limnigraphs)
However, in Croatia, major hourly data collection and systematic storing starts around year 2000 so availability of hourly data is rather limited. Also, in most cases, natural sub-daily variation of discharges is not so apparent, so there is perhaps a possibility to use daily data for assessment of reference conditions (undisturbed state).

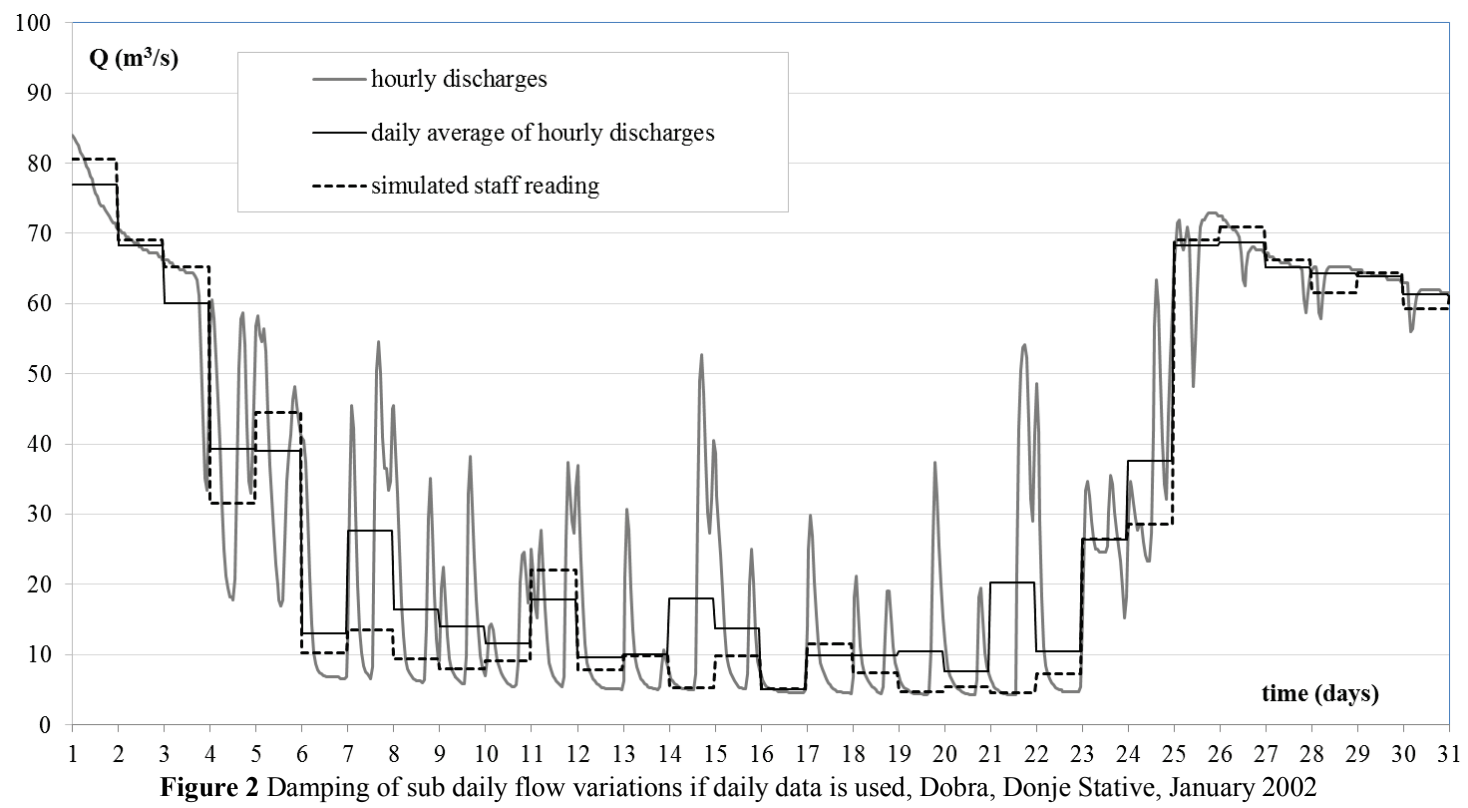


Quite large number of indicators for sub-daily flow variations have been published $[6,7,8,9]$. Unlike the others, exceptional place has two indicators defined in official CEN guidance standard EN 15843:2010 [10]. This standard was also starting point for draft guideline for hydromorphological monitoring and assessment of rivers in Croatia [11]. It should be noted that CEN is one of three European Standardization Organizations that have been officially recognized by the European Union as being responsible for developing and defining voluntary standards at European level. It is an association that brings together the National Standardization Bodies of 33 European countries and provides a platform for the development of European Standards and other technical documents in relation to various kinds of products, materials, services and processes $[12,13]$.

Within the same standard, thresholds for assessment of status are set as well. According to this standard in the category 5c: Effects of daily flow alteration, e.g. hydropeaking:

- if intervention results in flow for $<2 \%$ of the time (seven days per year) being at least doubled or halved, or rises/falls in level of $>5 \mathrm{~cm}$ per hour occurring, hydro morphological modification is nearnatural, and

- if intervention results in flow for $>2 \%$ to $5 \%$ of the time being at least doubled or halved, or rises/falls in level of $>5 \mathrm{~cm}$ per hour occurring hydro morphological modification is slightly modified

These features are defined as "core", meaning that they may be evaluated without reference to river type. Having all this in mind, the following questions are raised:

- What are the values of indicators defined in [10] for (near) natural gauging stations in the Danube catchment in Croatia, and are the limits for "nearnatural" and "slightly modified" status according to [10] in line with those values?

- Does the declaration of those parameters as "core" parameters, invariant to river type, hold?

- Is it possible to establish relationship of those parameters with $I H A_{5.1}$ and $I H A_{5.2}$. Existence of such (reliable) relationship would enable the use of far broader data set for definition of reference conditions. Also, it would give possibility to decrease already high number of parameters which must be taken into consideration in assessment of state.

\section{Indicator assessment method}

Indicators defined in [10] can be calculated in the following way:

$$
H P I_{1, i}=\frac{Q_{\max , i}}{Q_{\min , i}}
$$

where:

$Q_{\max , i}$ - maximal instantaneous (hourly) discharge that occurred during the $i^{\text {th }}$ day
$Q_{\min , i}-$ minimal instantaneous (hourly) discharge that occurred during the $i^{\text {th }}$ day

and

$H P I_{2, i}=\max \left|H_{i, j}-H_{i, j-1}\right|$

where:

$H_{i, j}$ - hourly water level recorded on the $j^{\text {th }}$ hour of the $i^{\text {th }}$ day.

Beside indicators $H P I_{1}$ and $H P I_{2}$, additional indicator $\mathrm{HPI}_{3}$, not defined in [10], is introduced:

$H P I_{3, i}=\max \left|Q_{i, j}-Q_{i, j-1}\right|$

where:

$Q_{i, j}$ - hourly discharge recorded on the $j^{\text {th }}$ hour of the $i^{\text {th }}$ day.

$\mathrm{HPI}_{3}$ is analogous to $\mathrm{HPI}_{2}$, except instead of water levels, discharge data have been used. Main reasoning for its introduction was that regionalisation of discharge based parameters is more common and often more reliable than regionalisation of parameters based on water levels and that in some cases it is easier to define operative rules based on discharges. Furthermore, from the ecological point of view, there should be no significant differences, because, in general terms, there is quite strong relationship between discharges and corresponding water levels so if natural discharge regime is preserved, it can be assumed that also natural water level regime is preserved as well (except in case of morphological changes which are not considered in this paper).

Here, parameters are defined on the level of a single day. By following [10], for each year, series of 365 (366 for leap year) elements is formed, and then from this series, average value and value of duration of $5 \%$ and 2 $\%$ is calculated.

From those calculated yearly values, multiannual series are formed which are denoted in the following text as $H P I_{1,5 \%}, H P I_{1,2 \%}, H P I_{2,5 \%}, H P I_{2,2 \%}, H P I_{3,5 \%} \quad$ and $H P I_{3,2} \%$.

If the watercourse is drying up (for certain number of days discharge $Q_{i, \min }=0$ ) it is not possible to calculate $H P I_{1}$. Because of that in some cases yearly series had less than 365 elements.

Unlike these indicators, Indicators of Hydrological Alterations are calculated on the basis of daily discharge data. In this paper indicators $I H A_{5,1}$ and $I H A_{5,2}$ (group "Rate/Frequency of Water Condition Changes") were considered. They are defined in the following way:

$I H A_{5,1}=\frac{\sum_{i=1}^{364}\left(Q_{i+1}-Q_{i}\right)\left[Q_{i}<Q_{i+1}\right]}{\sum_{i=1}^{364}\left[Q_{i}<Q_{i+1}\right]}$, 


$$
I H A_{5,2}=-\frac{\sum_{i=1}^{364}\left(Q_{i+1}-Q_{i}\right)\left[Q_{i}>Q_{i+1}\right]}{\sum_{i=1}^{364}\left[Q_{i}>Q_{i+1}\right]},
$$

where:

$I H A_{5,1}$ - "means of all positive differences between consecutive daily values"

$I H A_{5,2}$ - "means of all negative differences between consecutive daily values"

$Q_{i}$ - average daily discharge on the $i^{\text {th }}$ day of year. which:

In Eqs. (4) and (5) Iverson notation has been used by

$$
[P]=\left\{\begin{array}{lll}
1 & \text { for } & P=\text { True } \\
0 & \text { for } & P \neq \text { True }
\end{array}\right.
$$

For assessment of link (correlation), Spearman $(\rho)$ and Pearson $(r)$ coefficients of correlation have been used. Well known Pearson coefficient of correlation depicts linear relationship of two variables. On the other side, calculation of Spearman $\rho$ is based on ranks of data. This significantly decreases unfavourable influence of outliers and nonlinearity of the relationship (however, monotonicity of relationship is assumed). Detailed explanation of properties and calculation of this coefficient can be found in [14]. Significance of correlation coefficients is assessed by standard $\mathrm{T}$ test.

As this paper is part of wider exploration of Indicators of Hydrological Alterations in the Danube River basin in Croatia, starting set of gauging stations was taken from that study. To enable further analysis, from that set, gauging stations were selected for which, based on available information, it was concluded that they are not downstream from hydroelectric power plants or other structures which can produce significant influence on hydrological regime, and that at least 10-year of hourly data on water levels and/or discharges is available. Additional criteria was, that if within a certain year, more than 7 days $(2 \%)$ of data was missing, the whole year was considered as not available for analysis. In such a way sets of 49 gauging stations for water levels and 41 gauging stations for discharges have been selected (Fig. $3)$.

\section{Analysis of indicators in the Danube River basin in Croatia.}

Resulting values of all three sub-daily indicators $\left(H P I_{1}, H P I_{2}\right.$ and $\left.H P I_{3}\right)$ are presented in Figs. 4, 5 and 6.

From the multiannual series of indicators calculated at each gauging station, four parameters were selected (minimal, median, average and maximal value). Those parameters from all gauging stations, were rearranged to form four (for each parameter) sets of data (set of minimal values of indicator recorded on all gauging stations, set of median values of indicator recorded on all gauging stations etc.). In that way, four sets of data consisting of statistics from all gauging stations were formed for each hydro peaking indicator. Subsequently, on horizontal axis of Figs. 4, 5 and 6, percentages of gauging stations analysed (percentage of number of elements of data set) are plotted against indicator threshold (on vertical axis), which was not overpassed by corresponding number of gauging stations.

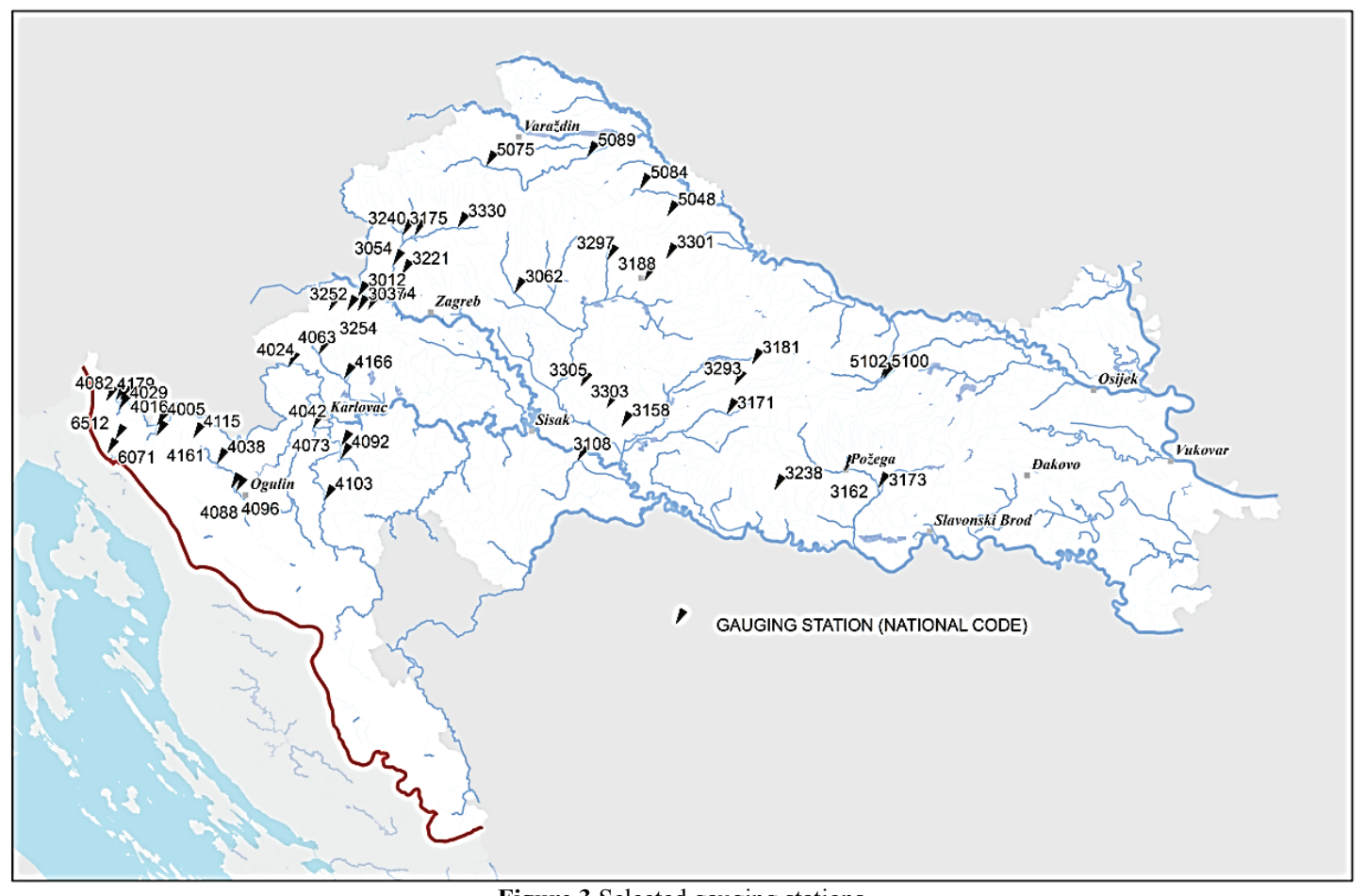

Figure 3 Selected gauging stations

From Figs. 4, 5 and 6, it is evident that the resulting hydro peaking indicators are significantly higher by approximately one fifth (20\%) of all gauging stations. On less than $10 \%$ gauging stations, thresholds set in [10] for "slightly modified" state have been met once in two years on average (median). At approximately $85 \%$ of stations, 
for half of analysed years, value of this indicator was less than 5, and maximal less than 9. At comparatively small number of stations, values of this indicator are significantly higher, overpassing value of 20. Concerning criteria for "near-natural" state, dispersion of the results is even higher, what was expected because it is a more "extreme" case.
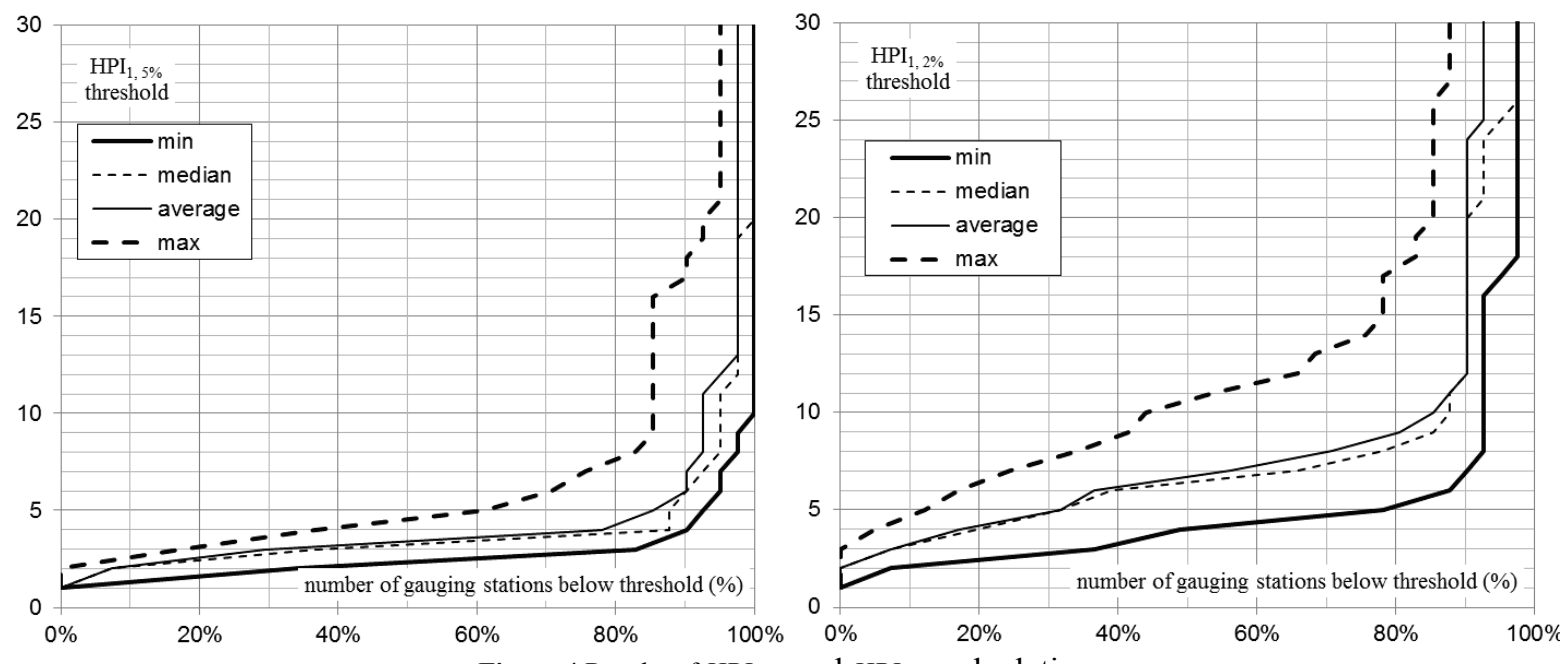

Figure 4 Results of $H P I_{1,5 \%}$ and $H P I_{1,2 \%}$ calculation
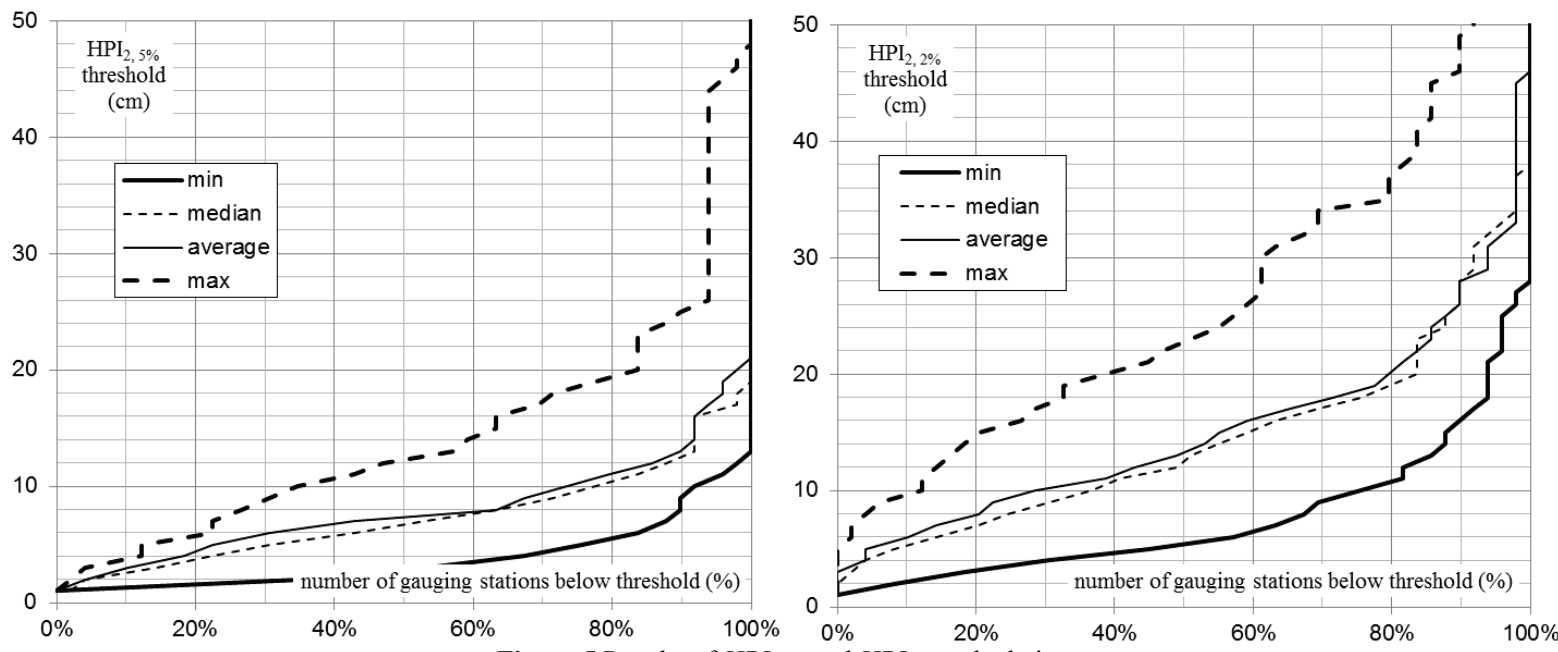

Figure 5 Results of $H P I_{2,5 \%}$ and $H P I_{2,2 \%}$ calculation
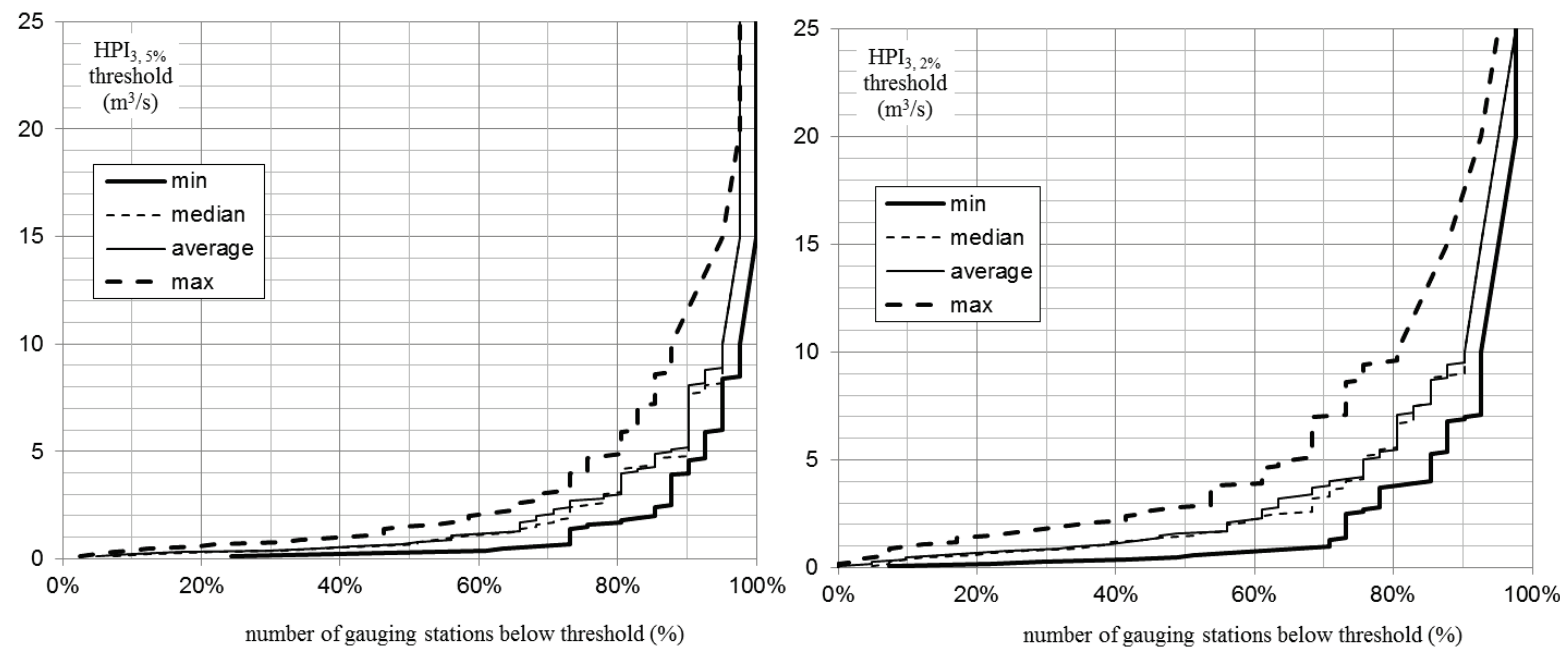

Figure 6 Results of $H P I_{3,5 \%}$ and $H P I_{3,2 \%}$ calculation

So for $85 \%$ of stations median is less than 9 . In most cases, very high values are result of the days when (minimal) flows were very low and then there was sudden increase, resulting in very high ratio.
Results for the $\mathrm{HPI}_{2}$ are slightly more in line with boundaries defined in [10]. Of all studied gauging stations, $4(8 \%)$ can be designated "near-natural" and 
additional 11 (22\%) as "slightly modified" every second year in average (median).

Indicator $\mathrm{HPI}_{3}$ is not contained in [10] and consequently there are not limit values to compare results to.

For three gauging stations data about watershed area have not been available. For all other gauging stations, average values of $H P I_{1,5 \%}, H P I_{2,5 \%}$ and $H P I_{3,5 \%}$ plotted against watershed area are displayed in Figs. 7, 8 and 9.

Strength of relationship between $H P I_{1}, H P I_{2}$, and $\mathrm{HPI}_{3}$ and basic descriptors of watershed size, watershed area $(A)$ and average flow $\left(Q_{\text {av }}\right)$ as well as indicators $I H A_{5.1}$ and $I H A_{5.2}$, based on Pearson correlation coefficient $(r)$, are summarised in Tab. 1. Corresponding results, based on Spearman correlation coefficient $(\rho)$, were in most cases quite comparable.

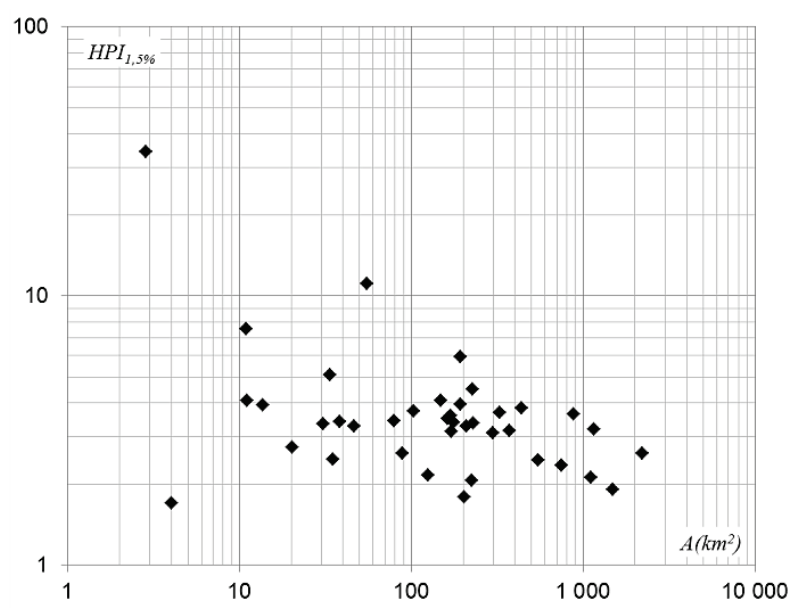

Figure 7 Average $H P I_{1,5 \%}$ related to catchment area

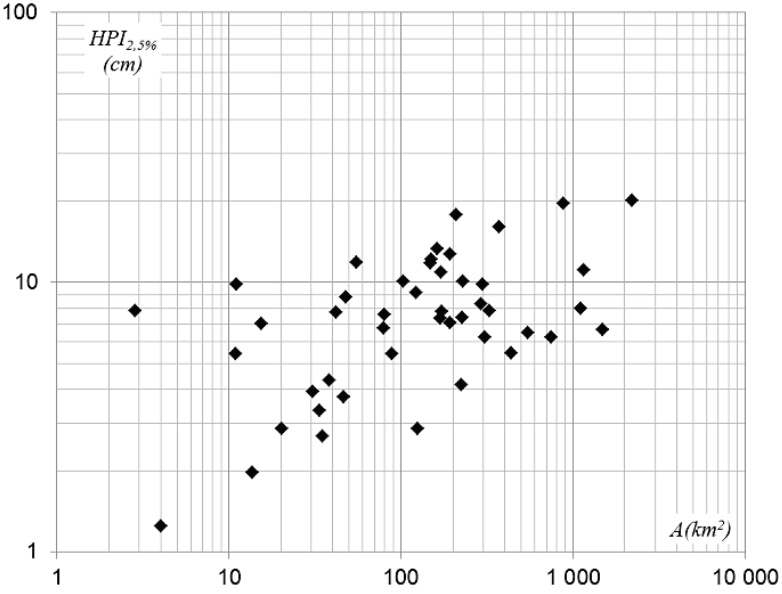

Figure 8 Average $H P I_{2,5 \%}$ related to catchment area

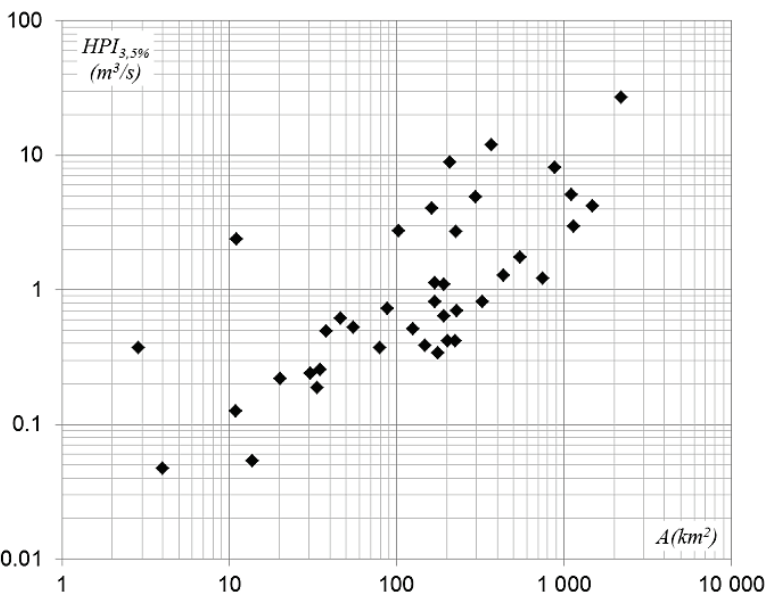

Figure 9 Average $\mathrm{HPI}_{3,5 \%}$ related to catchment area

Table 1 Pearson correlation coefficient

\begin{tabular}{|c|c|c|c|c|c|c|c|c|c|}
\hline \multicolumn{10}{|c|}{ Pearson $r$} \\
\hline & \multicolumn{3}{|c|}{$H P I_{1}$} & \multicolumn{3}{|c|}{$\mathrm{HPI}_{2}$} & \multicolumn{3}{|c|}{$\mathrm{HPI}_{3}$} \\
\hline & av & $5 \%$ & $2 \%$ & av & $5 \%$ & $2 \%$ & av & $5 \%$ & $2 \%$ \\
\hline$A$ & $-0,21$ & $-0,24$ & $-0,28$ & $0,55^{*}$ & $0,34^{*}$ & 0,19 & $0,63 *$ & $0,51 *$ & $0,5^{*}$ \\
\hline$Q_{\mathrm{av}}$ & $-0,17$ & $-0,2$ & $-0,25$ & $0,77^{*}$ & $0,62 *$ & $0,41 *$ & $0,97 *$ & $0,89 *$ & $0,85^{*}$ \\
\hline$I H A_{5,1}$ & $-0,16$ & $-0,19$ & $-0,21$ & $0,68^{*}$ & $0,68^{*}$ & $0,5^{*}$ & $0,92 *$ & $0,96^{*}$ & $0,96^{*}$ \\
\hline$I H A_{5,2}$ & $-0,16$ & $-0,19$ & $-0,23$ & $0,76^{*}$ & $0,67^{*}$ & $0,47 *$ & $0,96^{*}$ & $0,94 *$ & $0,91 *$ \\
\hline
\end{tabular}

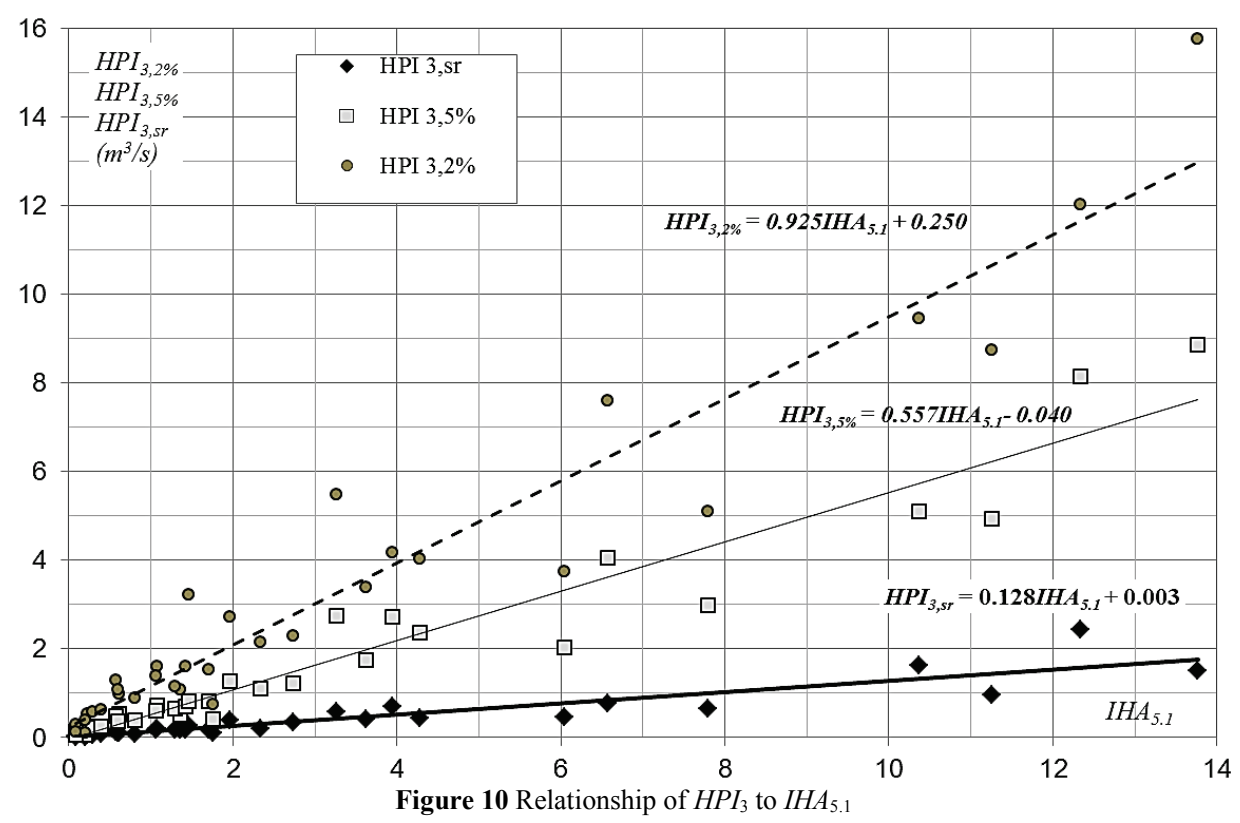


It is obvious that $H P I_{1}$ decreases with increase of descriptors of watershed size, and IHA. However this relationship is not statistically significant. A contrary link of $\mathrm{HPI}_{2}$ and $\mathrm{HPI}_{3}$ is statistically significant. Most of variation of these two indicators is explained with IHA, whilst relationship to watershed area is the weakest. Small differences between Spearman $\rho$ and Pearson $r$ indicate that in practical terms relationship with IHA can be interpreted as linear. Contrary higher differences of these two coefficients of correlation for descriptors of catchment size indicate that more reliable relation could be achieved with non-linear relationship. In Fig. 10, relationship of $\mathrm{HPI}_{3}$ to $\mathrm{IHA}_{5.1}$ is shown.

\section{Concluding remarks}

From analysis of sub-daily flow fluctuation indicators at gauging stations of the Danube River basin in Croatia on which there is no significant anthropogenic influence which could result in abrupt flow manipulation, can be concluded:

Basically, $H P I_{1}$ and $H P I_{2}$ significantly exceed values which are set in [10] as limits for "near-natural" and "slightly modified" state, or in other words boundaries defined seem to be too strict for the Danube River basin in Croatia.

Although $H P I_{1}$ decreases with increase of catchment size descriptors, as expected, this relationship is not statistically significant. Also there is not significant relation of this indicator with $I H A_{5.1}$ and $I H A_{5.2}$. It can be concluded that as far as the tested parameters are concerned, hypothesis of this parameter being "core" is not rejected (however it does not mean that there is no possibility of significant relationship to some other watercourse characteristic). It should be noted that calculation of this indicator is not clear when minimal daily flow is equal to 0 (it cannot be calculated) or very low (results in extremely high values) so calculation procedure should be further defined. Skipping of days with minimal flow equal to 0 from the point of calculation of referent conditions is not very important, but in case of existing flow manipulations it can influence (distort) assessment of actual status.

Values of $\mathrm{HPI}_{2}$, also significantly exceed limits of "near-natural" and "slightly modified" state as defined by [10]. This indicator increases with increase of descriptors of size of catchment. Although this relationship is statistically significant it explains rather small part of variation of the sample. It should be reconsidered whether this parameter can be considered as "core" or it should be related to catchment size. Relatively high dispersion of results (difference between minimal and maximal values in figure) indicates that application of this indicator in practice is less reliable than others, unless some further improvement is done.

Consequently, it is recommended that for the more reliable application on the Danube River Basin in Croatia, thresholds set for $H P I_{1}$ and $H P I_{2}$ should be carefully reconsidered, and procedure for calculation of $H P I_{1}$ should be defined in more detail to prevent possible misinterpretations.

Indicator $\mathrm{HPI}_{3}$ is characterised with statistically significant relationships to all tested parameters.
According to correlation coefficients, relationship to both IHA is reliable $\left(r^{2}>0,82\right)$ and linear. This indicates intriguing possibility of using significantly larger pool of daily data for definition of reference conditions for subdaily flow variations, or in other words that it is possible to define dynamics of undisturbed catchments (if indicators similar to those analysed in this paper are used) on the basis of daily data. In any case this hypothesis should be additionally investigated and it is not valid for catchments where anthropogenic disturbances exist. It seems that discharge based indicators have some advantages such as status assessment (it is clear that magnitude of alteration decreases downstream due to natural lateral inflows, there is no assessment needed where referent water levels should be measured, etc.), more reliable regionalisation (as in this paper) etc. Therefore, from the hydrological point of view, it is advantageous to use $\mathrm{HPI}_{3}$ in the place of $\mathrm{HPI}_{2}$, having in mind that both of those indicators describe essentially the same phenomenon.

Reliable relationship of $H P I_{3}$ to $I H A_{5.1}$ and $I H A_{5.2}$ contributes to the hypothesis that such indicators based on daily data can be used for description of hydrological dynamics of undisturbed watersheds. However, it is recommended that this hypothesis should be investigated in more detail.

In this paper exploration of sub-daily flow fluctuations is not exhausted. It is sure that more reliable information will be obtained when longer time series are available, which will unfortunately require quite long time. Also significant progress can be achieved by improving knowledge of impact of hydrological alterations to ecological status of waters, which is also a long term activity.

\section{References}

[1] Directive 2000/60/EC of the European Parliament and of the Council of 23 October 2000, establishing a framework for community action in the field of water policy, European Parliament and of the Council, 2000.

[2] Poff, N. L.; Zimmerman, J. K. H. Ecological responses to altered flow regimes: a literature review to inform the science and management of environmental flows. // Freshwater Biology. 55, (2010), pp. 194-205. DOI: 10.1111/j.1365-2427.2009.02272.x

[3] Richter, B.; Baumgartner, J.; Powell, J.; Braun, P. A Method for Assessing Hydrologic Alteration within Ecosystems. // Conservation Biology. 10, 4(1996), pp. 1163-1174. DOI: 10.1046/j.1523-1739.1996.10041163.x

[4] Richter, B.; Baumgartner, J.; Wigington, R.; Braun, P. How much water does a river need? // Freshwater Biology. 37, (1997), pp. 231-249. DOI: 10.1046/j.1365-2427.1997.00153.x

[5] Tharme, R. E. A Global Perspective on Environmental Flow Assessment: Emerging Trends in the Development and Application of Environmental Flow Methodologies for Rivers. // River Research and Applications. 19 (2003), pp. 397-441. DOI: 10.1002/rra.736

[6] Meile, T.; Boillat, J. L.; Schleiss, A. J. Hydropeaking indicators for characterization of the Upper-Rhone River in Switzerland. // Aquatic Sciences. 73, (2011), pp. 171-182. DOI: 10.1007/s00027-010-0154-7

[7] McManamay, R. A.; Bevelhimer, M. S. A Holistic Framework for Environmental Flows Determination in Hydropower Contexts. ORNL/TM-2013/159. Oak Ridge National Laboratory, 2013. DOI: 10.2172/1128963 
[8] Baker, D. B.; Richards, P.; Lofus, T. T.; Kramer, J. W. A New Flashiness Index: Characteristics and Applications to Midwestern Rivers and Streams. // Journal of the American Water Resources Association (JAWRA). 40, 2(2004), pp. 503-522. DOI: 10.1111/j.1752-1688.2004.tb01046.x

[9] Pfaundler, M.; Dübendorfer, C.; Zysset, A. Methoden zur Untersuchung und Beurteilung der Fliessgewässer. Hydrologie - Abflussregime Stufe F (flächendeckend). Bundesamt für Umwelt, Bern. Umwelt-Vollzug Nr. 1107: 113 S. 2011.

[10] CEN/TC 230 (2010): Water quality - Guidance standard on determining the degree of modification of river hydromorphology, EN 15843:2010

[11] Guideline for Hydromorphological Monitoring and Assessment of Rivers in Croatia, Proposal, Hrvatskevode, 2013, http://www.voda.hr/ (02.02.2015)

[12] Regulation No 1025/2012 of the European Parliament and of the Council of 25 October 2012, L 316/12, Official Journal of the European Union, 2012.

[13] European Committee for Standardization - Official Site. http://www.cen.eu/ (02.02.2015.)

[14] Helsel, D. R.; Hirsch, R. M. Statistical Methods in Water Resources, Techniques of Water-Resources Investigations of the United States Geological Survey. United States Geological Survey, 2002.

\section{Authors' addresses}

Darko Barbalić, BSc. CE

Hrvatske vode, Zavod za vodno gospodarstvo

Ulica grada Vukovara 220

10000 Zagreb, Croatia

E-mail: darkob@voda.hr

Prof. Neven Kuspilić, PhD. CE

Građevinski fakultet Sveučilišta u Zagrebu

Kačićeva 26

10000 Zagreb, Croatia

E-mail: kuspa@grad.hr 